\title{
Blood Pictures in Stomach Cancer, Especially on Their Relation with Cancer Progress
}

\author{
Third Report : Serum Calcium
}

By

\author{
Iwao Yamaguchi, Tsunemasa Suzuki and Ryoichi Motoki \\ From Prof. M. M u to's Surgical Clinic, School of Medicine, \\ Tohoku University, Sendai
}

(Received for publication, July 14, 1960)

Changes in the serum sodium and potassium content in stomach cancer have been clarified by many authors including those in our clinic. ${ }^{112}$ In the present communication will be reported the results of serum calcium analysis.

Needless to say, calcium is contained in the serum in two main forms, one is the ionized or dialyzable fraction responsible for the physiological activities of serum calcium and the other is the combined calcium regarded as a depot of the former. These two fractions were treated separately in this work.

\section{EXPERIMENTAL AND COMMENTS}

\section{METHOD}

The objects for this study were 68 cases with stomach cancer $(46$ males and 22 females, aged 26 to 65 years), as well as 20 healthy adults and 23 cases with peptic ulcer of the stomach and/or duodenum for comparison. The quantitative analysis of serum calcium was carried out by Yanagisawa's method, ${ }^{3)}$ as follows :

1) Total calcium. A $0.1 \mathrm{cc}$ portion of the serum was diluted with $0.4 \mathrm{cc}$ of redistilled water, to which were added $2.0 \mathrm{cc}$ of $0.00025 \mathrm{M} / 1$. 1-hydroxy4-chloro-2,2-diazobenzene-1,8-dihydroxy-naphthalene-3,6-disulfonic acid disodium salt (Plasmo Corinth B, Sumitomo) and $2.5 \mathrm{cc}$ of $2 N$ sodium hydroxide. After three minutes, the mixture, a red transparant solution, was subjected to the photometry at $634 \mathrm{~m} \mu$, against the blank solution prepared similarly but using redistilled water instead of the serum. From the transmittance thus obtained, the concentration of total calcium was determined on the standard curve prepared previously.

2) Combined calcium. The procedure for measuring the concentration of the combined calcium was essentially the same as above except that a 4.0 
per cent solution of ammonium oxalate was used in place of redistilled water as the diluent of the serum. At that time, Plasmo Corinth B was added exactly three minutes after the serum had been mixed with the oxalate solution.

3) Ionized calcium. The concentration of the ionized calcium (hereafter to be referred to as $\mathrm{Ca}^{++}$) was calculated as the difference between those of the total and the combined calcium. The ionization quotient (I.Q.) was also calculated for reference, as $\mathrm{Ca}^{++} /$total $\mathrm{Ca}$.

\section{RESULTS}

\section{Normal Values}

The mean values in 20 healthy adults were $9.6 \pm 0.3 \mathrm{mg} / \mathrm{d} l$ for total Ca, $4.4 \pm 0.2 \mathrm{mg} / \mathrm{d} l$ for $\mathrm{Ca}^{++}$, and $0.46 \pm 0.01$ for the I.Q. From the individual values obtained, the normal range of total $\mathrm{Ca}^{++}$and $\mathrm{Ca}$ was calculated as an area surrounded by the ellipse having the formula ${ }^{4}$

$$
0.98(x-9.6)^{2}-2 \times 0.37(x-9.6)(y-4.4)+2.84(y-4.4)^{2}-1=0
$$

where $\mathrm{x}$ is the concentration of total $\mathrm{Ca}$ and $\mathrm{y}$ is that of $\mathrm{Ca}^{++}$. Hereafter in this report, the "abnormal" pattern of serum calcium means that a pair of total Ca and $\mathrm{Ca}^{++}$is outside of the mentioned ellipse, or, in other words, that the substitution of the numerical values of $x$ and $y$ gives a positive value to the left side of the above equation.

\section{Results with Stomach Cancer Cases}

The serum calcium figures in the stomach cancer cases are shown in Table I with those of the control cases. A characteristic of the cancer cases was a lowering of T.Q. and in this point they differed from the ulcer cases, though a decrease in total $\mathrm{Ca}$ and in $\mathrm{Ca}^{++}$was observed to be common to these two groups. This suggests that the decrease in the ionized calcium in stomach cancer is due to a depressed dissociation in addition to a depletion of total serum calcium, while that is due only to a loss of serum calcium in the case of peptic ulcer.

Abnormal patterns of serum calcium was found in almost 90 per cent of the cancer cases, in significantly higher rate than in the ulcer cases.

Table I. Serum Calcium Content in Stomach Cancer and in Controls

\begin{tabular}{l|c|ccc|c}
\hline \multicolumn{1}{c|}{ Cases } & $\begin{array}{c}\text { No. of } \\
\text { total } \\
\text { cases }\end{array}$ & $\begin{array}{c}\text { Total Ca } \\
(\mathrm{mg} / \mathrm{d} l)\end{array}$ & $\begin{array}{c}\mathrm{Ca} \\
(\mathrm{mg} / \mathrm{d} l)\end{array}$ & I.Q. & $\begin{array}{c}\text { No. of cases } \\
\text { with abnormal } \\
\text { patterns }\end{array}$ \\
\hline Healthy adults & 20 & $9.6 \pm \mathbf{0 . 3}$ & $4.4 \pm 0.2$ & $0.46 \pm 0.01$ & 0 \\
Peptic ulcer & 23 & $8.3 \pm 0.4$ & $3.9 \pm 0.5$ & $0.47 \pm 0.06$ & $18(78.3 \%)$ \\
Stomach cancer & 68 & $7.9 \pm \mathbf{0 . 2}$ & $3.1 \pm 0.3$ & $0.38 \pm 0.03$ & $61(89.6 \% 6)$
\end{tabular}

* With 95 per cent confidence ranges.

Relation with the extent of cancer progress 
The concentration of total $\mathrm{Ca}$ and $\mathrm{Ca}^{++}$in the stomach cancer cases are shown in Table II for various extent of the cancer spreads. Both the concentrations, especially that of $\mathrm{Ca}^{++}$, were significantly low and the rate of occurrence of the abnormal patterns of serum calcium was extremely high in cases with the progressed disseminations or with the widespread metastasis, and consequently in those at the advanced stage of cancer progress.

Table II. Relation of Serum Calcium Figures in Stomach Cancer with Extent of Cancer Progress

\begin{tabular}{|c|c|c|c|c|c|}
\hline \multicolumn{2}{|c|}{ Cancer spreads* } & \multirow{2}{*}{$\begin{array}{l}\text { No. of } \\
\text { total } \\
\text { cases }\end{array}$} & \multicolumn{2}{|c|}{ Mean values $(\mathrm{mg} / \mathrm{d} l)$} & \multirow{2}{*}{$\begin{array}{c}\text { No. of cases } \\
\text { with abnormal } \\
\text { patterns }\end{array}$} \\
\hline & & & Total $\mathrm{Ca}$ & $\mathrm{Ca}^{++}$ & \\
\hline \multirow{4}{*}{$\begin{array}{l}\text { Peritoneal } \\
\text { dissemination }\end{array}$} & P.C. & 8 & $8.4 \pm 0.6$ & $3.9_{ \pm 0} 0.9$ & $5(62.5 \%)$ \\
\hline & I & 24 & $8.1 \pm 0.3$ & $3.0 \pm 0.4$ & $22(91.7 \%)$ \\
\hline & II & 29 & $7.8 \pm 0.3$ & $3.0 \pm 0.4$ & $27(93.1 \%)$ \\
\hline & III & 7 & $7.6 \pm 0.7$ & $2.4 \pm 0.4$ & $7(100.096)$ \\
\hline \multirow{3}{*}{$\begin{array}{l}\text { Lymph-nodal } \\
\text { involvernent }\end{array}$} & L.M. & 6 & $8.2 \pm 0.8$ & $3.7 \pm 0.6$ & $3(50.096)$ \\
\hline & $\mathrm{I}$ & 10 & $8.1 \pm 0.7$ & $3.5 \pm 0.7$ & $8(80.0 \%)$ \\
\hline & II, III & 47 & $7.9 \pm 0.5$ & $2.8 \pm 0.3$ & $45(95.7 \%)$ \\
\hline \multirow{3}{*}{$\begin{array}{l}\text { Stage of } \\
\text { progress }\end{array}$} & Stage I & 11 & $8.3 \pm 0.4$ & $3.6 \pm 0.4$ & $7(63.3 \%)$ \\
\hline & II & 48 & $7.9 \pm 0.2$ & $2.9_{ \pm 0.4}$ & $45(93.7 \%)$ \\
\hline & III & 9 & $7.5 \pm 0.7$ & $2.5 \pm 0.5$ & $9(100.0 \%)$ \\
\hline
\end{tabular}

* For explanations, see Table II of the First Report.4)

Relation with morphology of the main tumor (Table III)

Though $\mathrm{Ca}^{++}$content was comparatively low in cases with large tumors,

TABLE III. Relation of Serum Caloium Figures in Stomach Cancer with Morphology of the Tumor*

\begin{tabular}{|c|c|c|c|c|c|}
\hline \multirow{2}{*}{\multicolumn{2}{|c|}{ Morphology }} & \multirow{2}{*}{$\begin{array}{c}\text { No. of } \\
\text { total } \\
\text { cases }\end{array}$} & \multicolumn{2}{|c|}{ Mean values $(\mathrm{mg} / \mathrm{d} l)$} & \multirow{2}{*}{$\begin{array}{l}\text { No. of cases } \\
\text { with abnormal } \\
\text { patterns }\end{array}$} \\
\hline & & & Total $\mathrm{Ca}$ & $\mathrm{Ca}^{++}+$ & \\
\hline \multirow{3}{*}{ Size } & Small & 16 & $8.1 \pm 0.4$ & $3.2 \pm 0.4$ & $13(81.2 \%)$ \\
\hline & Medium & 16 & $7.9 \pm 0.4$ & $3.2 \pm 0.3$ & $16(100.0 \%)$ \\
\hline & Large & 27 & $8.0 \pm 0.3$ & $2.8 \pm 0.4$ & $23(85.2 \%)$ \\
\hline \multirow{2}{*}{$\begin{array}{l}\text { Gross } \\
\text { appearance }\end{array}$} & Circumscribed & 47 & $8.0 \pm 0.2$ & $3.1 \pm 0.3$ & $42(89.4 \%)$ \\
\hline & Infiltrative & 12 & $7.9 \pm 0.5$ & $3.0 \pm 0.8$ & $10(83.3 \%)$ \\
\hline \multirow{3}{*}{$\begin{array}{l}\text { Histological } \\
\text { feature }\end{array}$} & Adenomatosum & 27 & $7.9 \pm 0.2$ & $3.2 \pm 0.4$ & $23(85.2 \%)$ \\
\hline & Solidum & 28 & $8.0 \pm 0.2$ & $3.0 \pm 0.4$ & $25(89.3 \%)$ \\
\hline & Mixed & 4 & & & \\
\hline
\end{tabular}

* In 59 cases subjected to gastrectomy.

$\dagger$ Cf. Table III of the First Report.4) 
such a close relation as in the case of the serum protein figures ${ }^{5)}$ and the red cell pictures $^{6)}$ was not observed between the serum calcium figures and the size of the tumor. The serum calcium figures were, on the other hand, found to depend neither upon the gross features nor upon the histological views of the main tumor.

\section{SUMMARY}

Serum calcium figures in stomach cancer were studied with special interest to their relation with the morphological aspects of the lesion, taking ionization of serum calcium into consideration.

1) The concentration of serum calcium, especially that of the ionized calcium, was generally low in stomach cancer, and significantly lower even when compared with peptic ulcer cases. The abnormal patterns of serum calcium, defined from both the concentration and the extent of dissociation, were found in 89.6 per cent of the stomach cancer cases.

2) The serum calcium figures in stomach cancer were closely dependent upon the extent of the cancer spreads that was revealed by operations, a little upon the tumor size, but wholly not upon the gross nor microscopic features of the tumor.

\section{References and Note}

1) Misawa, Tohoku Ig. Z. (Jap.), 1956, 53, 314.

2) Murooka, ibid., 1957, 55, 445.

3) Yanagisawa, Niigata Igk. Z. (Jap.), 1951, 65, 838; 1952, 66, 90.

4) Calculated as the rejection limits at five per cent probability of the possible error.

5) Yamaguchi, Nishiyama, Inoue \& Yoshinari, Tohoku J. Exper. Med,, 1960, 72, 405.

6) Yamaguchi \& Okuguchi, itid., 1960, 73, 22 . 